\title{
ANALYSIS OF TENDENCIES IN THE FUNCTIONING OF INNOVATIVE ENTREPRENEURSHIP IN THE CONTEXT OF TECHNOLOGICAL PROGRESS
}

\author{
Eshgin Bayramov ${ }^{1}$ \\ ${ }^{1}$ Baku Business University, Azerbaijan \\ E-mail: bayramove@i.ua \\ ORCID: https://orcid.org/0000-0003-3129-9669
}

\begin{tabular}{|c|}
\hline $\begin{array}{l}\text { Article history: } \\
\text { Received date } 16.11 .2021 \\
\text { Accepted date 21.12.2021 } \\
\text { Published date 30.12.2021 }\end{array}$ \\
\hline $\begin{array}{l}\text { Section: } \\
\text { Technology transfer }\end{array}$ \\
\hline DOI \\
\hline $10.21303 / 2313-8416.2021 .002198$ \\
\hline KEYWORDS \\
\hline $\begin{array}{l}\text { innovative entrepreneurship } \\
\text { technological progress } \\
\text { frontier technologies } \\
\text { market indicators globalization }\end{array}$ \\
\hline
\end{tabular}

market indicators globalization
ABSTRACT

The object of research is innovative entrepreneurship and the main tendencies in its operation in the world.

Investigated problem. The rapid development of innovative entrepreneurship necessitates are the identification and tracking of tendencies in this area.

The main scientific results. The article identifies tendencies in the functioning of entrepreneurship in the context of technological progress. The main subsystems of an innovative enterprise are characterized. The dynamics of frontier technologies market indicators in the context of innovative entrepreneurship is analyzed. It is noted that the transformation of the structure of the global market of advanced technologies is accompanied by increasing disparities in technological and financial development between countries. The inconsistency of national goals with global ones in the field of frontier technologies is pointed out.

The area of practical use of the research results. The results of the study can be used by representatives of the scientific community, authorities to understand global tendencies in innovative entrepreneurship.

Innovative technological product. Identified global tendencies in the functioning of innovative entrepreneurship can be part of technological development strategies.

Scope of application of the innovative technological product: policy of regulation of innovation activity.

CC The Author(s) 2021. This is an open access article under the Creative Commons CC BY license

\section{Introduction}

Civilizational development of the late II-early III millennium was characterized by increasing tendencies of globalization. It causes the rapid spread of innovation in the world, regardless of the country of manufacture. Globalization makes it possible for innovative business entities from different countries to cooperate, and sometimes virtual communications are enough for such cooperation. In addition, globalization greatly simplifies the movement of material values, technology, labor between countries. However, the COVID-19 pandemic, on the one hand, has significantly slowed down the process of globalization due to the closure of borders between countries, restrictions on economic activity, it has affected the transformation of the global market, including innovation. On the other hand, the pandemic has become a catalyst for innovation in certain sectors of the economy, including biotechnology, robotics and others.

That is why the issue of innovative entrepreneurship, which has become especially relevant with the transition of the world economy to Industrial 4.0, in the medium term will only attract attention. Accordingly, the study of the main tendencies in the functioning of innovative entrepreneurship is relevant.

\section{1. The object of research}

The object of research is current innovative entrepreneurship and the main tendencies in its operation in the world.

\section{2. Problem description}

The article [1] is devoted to the problem of the dependence of the development of innovative entrepreneurship on the resource potential. The author, refers to the generalization of the basic 
theories of entrepreneurship, offers an interpretation of the essence and main characteristics of the entrepreneur-innovator. It is noted that financial and intellectual resources are essential for the development of innovative entrepreneurship. Entrepreneurs point out the need to intensify networks of social connections, which will help to obtain financial resources [1].

In the article [2], innovative entrepreneurship is considered as a major factor in modern economic development. The author notes that the EU development strategy is based on the entrepreneurial sector and innovation. That is why the article analyzes the role of innovative entrepreneurship in the economic development of EU countries. To this end, the influence of new innovative companies as determinants of development on the dynamics of the main macroeconomic indicators was studied. The results of the study [2] showed that innovative entrepreneurship is concentrated in economically developed countries. The author concludes that it is necessary to implement a state policy to promote entrepreneurship and use tools to support it.

Quite interesting, from a scientific point of view, is the view of the innovative entrepreneur as a factor of economic change presented in the article [3]. According to the author, the role of the entrepreneur is to ensure the process of transformation of capitalism. It is noted that in addition to producing innovations, the modern entrepreneur also performs other functions, such as creating working places. The author [3] concludes that the entrepreneurial economy should be understood as a common space between the theories that consider the entrepreneur, on the one hand, as a participant in controlled changes, and on the other - as a subject of the economic system.

The article [4] is devoted to the study of the influence of factors on the development of entrepreneurship on the example of a specific country. The article examines the relationship between creativity and innovation, on the one hand, and the development of entrepreneurship on the other. For this purpose, the authors formed a sample of 257 people. Data analysis was done using the Yemane method and using the ANOVA Test and Ordinary Least Square method. The main variables to be defined are technological progress and strategy. The results of the analysis [4] showed a close relationship between creativity and innovation, as well as technological progress.

The article is devoted to a similar topic [5]. The article analyzes the main tendencies of financing innovation activity in Ukraine. The authors [5] substantiate the relationship between the volume of funding for innovations and the sale of innovative products. The directions which will promote increasing a level of financing of subjects of innovative activity are offered.

The aim of research is to identify and analyze tendencies in the functioning of innovative entrepreneurship in the context of modern technological progress.

\section{Materials and Method}

The study of tendencies of the functioning of innovative entrepreneurship required the use of the following methods. The application of the method of expert assessments allowed to determine the prospects and tendencies of the market of frontier technologies. The method of generalization allowed to determine the characteristic features of the functioning of modern innovative entrepreneurship. Using the method of comparative analysis allowed to compare countries by specific economic and technological indicators.

\section{Results and Discussion}

The functioning of innovative entrepreneurship in the context of modern technological progress is characterized by the presence of several tendencies:

- first, the growing role of the entrepreneurial sector in producing innovations;

- secondly, the time from the birth of an innovative idea to its realization, implementation is reduced;

- thirdly, there is a process of increasing the volume of the frontier technologies market and transforming its structure;

- fourthly, the growth of technological and financial inequality between countries and regions of the world;

- fifthly, the low degree of coherence of national advanced technology development strategies with global ones.

In previous periods, the role of the entrepreneurial sector in producing innovations was not significant. The vast majority of innovations were created in academic research institutions and 
only later were they introduced into production. The relationship between the producers of innovation and the entrepreneurial structures that implemented them was weak. The synthesis of business and science, which was formed in the middle of the last century, led to the rapid spread of innovative entrepreneurship. We are not talking about isolated cases, but about the direct and systematic participation of business in the production of innovations, the organization of the technological process and the manufacture of innovative products.

The modern phenomenon of innovation enterprise combines several important subsystems: education (science), financial resources, mobility/adaptability to changes in the external environment, the state of readiness to innovate and the level of state support.

The absence of at least one of these elements makes it impossible for the modern understanding of the entrepreneurial entity as innovative.

Acceleration of scientific and technological progress leads to the rapid development of the market for innovative entrepreneurship.

According to an analytical report [6], the market size of frontier technologies in the period up to 2025 will increase from 0.35 trillion dollars to 3.2 trillion dollars, it means 9.1 times.

Analysis of Fig. 1 shows that in the period up to 2025 there will be a significant change in the market structure of frontier technologies. The largest share in the market structure of frontier technologies will be occupied by IoT with a rate of $46.8 \%$. Leaders in the growth of the share will be IoT $(+9.7 \%)$, $5 \mathrm{G}$ technology $(+8.0 \%)$ and robotics $(+6.5 \%)$. Instead, the share of Drones $(-15.3 \%)$ and Solar PV (-4.7\%) technologies will decrease significantly.

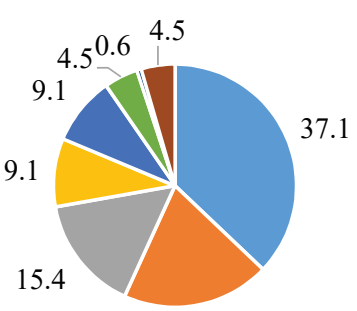

19.7

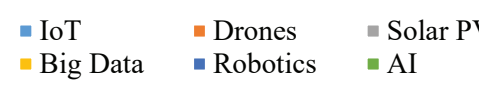

a
2018

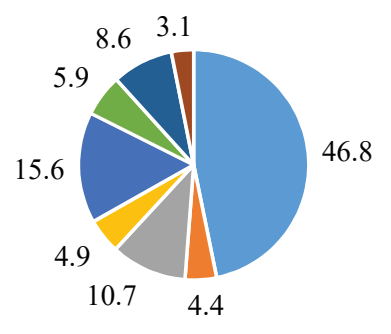

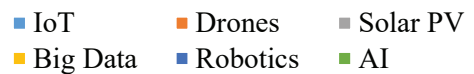

b

Fig. 1 Market size estimates of frontier technologies, \%: $a-2018 ; b-2025$. Source: [6]

The mentioned above is fully confirmed by the [7, 8], which state that economies of scale and diversification, as well as the networking nature of many advanced technology-based platforms such as search engines, cloud technologies and artificial intelligence, are launching, which will eventually lead to market concentration.

The development of innovative entrepreneurship, its participation in international processes of innovation production and technology transfer requires appropriate technical and technological readiness for the production and implementation of frontier technologies.

The assessment of the ability of a particular country to implement the modern concept of innovative entrepreneurship and be technologically ready to produce frontier technologies is based on the relevant indices. They allow to summarize information and make possible the comparative analysis. In this study, the author used analytical materials of Network Readiness Index [9]. This index is based on four main elements: technology, people, governance and influence.

The results of the study showed that the transformation of the structure of the global market for frontier technologies is accompanied by growing technological and financial inequality between countries and regions of the world.

Actually, the data in Table 1 show significant changes in the positioning of countries in the Network Readiness Index depending on the level of income. In particular, in 2020, the highest $34^{\text {th }}$ position among the countries with Upper middle-income was occupied by Malaysia. At the same 
time, in 2016 it occupied a higher position than in 2020. The situation is similar for the leading countries in other income groups. In addition, in 2020, among the 50 leading countries in the Network Readiness Index, 46 countries belonged to the group of High-income, and 4 countries - to the Upper middle-income. In 2016, the situation was different - in the top 50 leaders 6 countries belonged to the group Upper middle-income.

Table 1

Top 3 countries by income group (Network Readiness Index)

\begin{tabular}{ccccc}
\hline Year & High-income & Upper middle-income & Lower middle-income & Low-income \\
\hline \multirow{2}{*}{2020} & 1. Sweden (1) & 1. Malaysia (34) & 1. Viet Nam (62) & 1. Rwanda (96) \\
& 2. Denmark (2) & 2. China (40) & 2. Ukraine (64) & 2. Tajikistan (109) \\
& 3. Singapore (3) & 3. Bulgaria (46) & 3. Moldova (71) & 3. Uganda (114) \\
\multirow{2}{*}{2016} & 1. Singapore (1) & 1. Malaysia (31) & 1. Armenia (56) & 1. Rwanda (80) \\
& 2. Finland (2) & 2. Kazakhstan (39) & 2. Georgia (58) & 2. Cambodia (109) \\
& 3. Sweden (3) & 3. Costa Rica (44) & 3. Sri Lanka (63) & 3. Gambia (113)
\end{tabular}

Source: $[10,11]$

Processes to increase disparities in the technology sector are similar in other areas, in particular in the financing of innovative entrepreneurship frontier technologies.

The results of the analysis of Fig. 2 show that for the period of 2014-2018 the lag of the countries from the Low \& middle income group has not decreased, compared to the High income group, and is 1.13 percentage points.

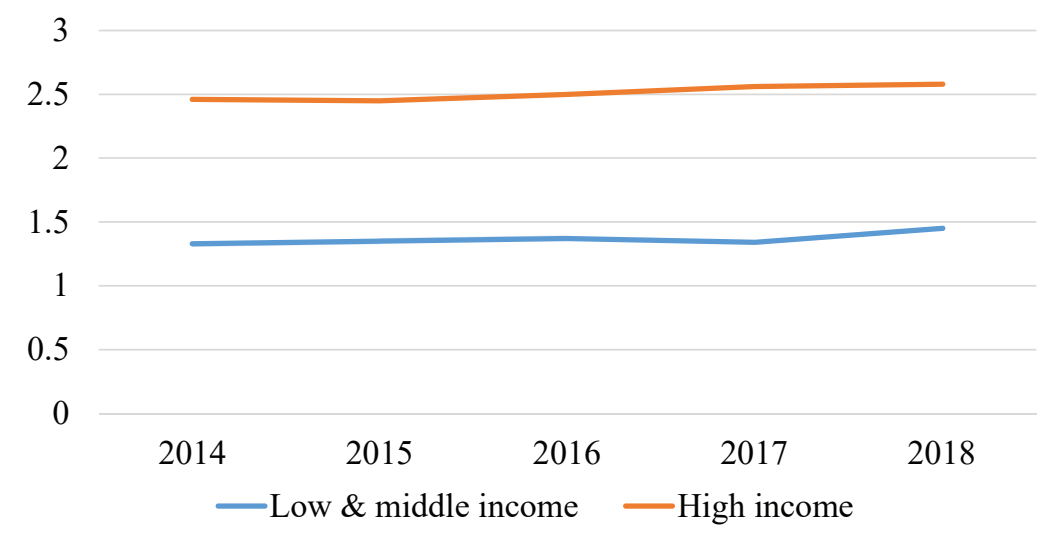

Fig. 2. Research and development expenditure (\% of GDP). Source: [12]

An important role in financing innovative developments and financial support for innovative entrepreneurship is played by the ability of the entities themselves to attract financial resources. Innovative entrepreneurs of developed countries cope with this task much better than other countries.

In particular, the data of the report [13] show that innovative entrepreneurs from Upper-middle Income countries have attracted 1.0 billion dollars more funding from the World Bank than Lower-middle countries and 0.35 billion dollars more than from the group Low income (Table 2).

Table 2

Lending to innovative projects, in terms of groups of countries by income, billion dollars

\begin{tabular}{ccc}
\hline Income Category & Lending for Innovation Components & Average Lending per Project \\
\hline Lower & 1.352 & 0.028 \\
Lower-middle & 0.708 & 0.02 \\
Upper-middle & 1.711 & 0.078 \\
Total & 3.771 & 0.036
\end{tabular}

Source: [13] 
This indicates the strengthening of technological inequality and financial disparities among countries in the field of innovative entrepreneurship.

\section{Discussion}

In [7], it is noted that the fixed costs of broadband connection in the least developed countries are about $54 \%$ of gross national income per capita compared to $1.4 \%$ in developed countries. Expenditures on mobile Internet account for $1 \%$ of gross national income per capita in developed countries, $4.5 \%$ in developing countries and $9.8 \%$ in least developed countries [14]. However, mobile Internet is not always sufficient in terms of data rates required by advanced technologies [7].

The development of innovative entrepreneurship in each country is in accordance with national strategies in the field of frontier technologies. Given that the goals of national strategies are focused on local priorities, this leads to inconsistencies with global strategies. In [7] notes that most of the developed national strategies on artificial intelligence, big data and the Internet of Things focus on increasing the competitiveness of the industry. Instead, the issue of creating incentives for technological changes in the above-mentioned areas in favor of achieving the goals of sustainable development has not been given sufficient attention [7].

For example, mitigating climate change to limit warming by $1.5^{\circ} \mathrm{C}$ requires innovation to reduce energy demand and emissions in agriculture, decarbonize electricity and other energy sources, and remove carbon dioxide from the earth $/$ s surface $[7,15]$. But, at the same time, demand and prices for energy, including coal and gas, are rising. According to estimates set out in the [16], it is noted that in 2021 the expected resumption of economic activity will increase by $4.5 \%$ of global coal demand compared to 2019. In addition, experts expect that gas prices will also rise in 2021, which will lead to partial use of coal, especially in the United States and the European Union [16].

An important factor in the development of innovative entrepreneurship is the transformation of the educational component. In particular, the article [17] highlights current issues of reforming the national education system in the context of the paradigm of technological development.

Restrictions in the article are related to the use of statistics prior to the COVID-19 pandemic. Taking into account the significant impact of the pandemic on global economic and scientific and technical activity, the use of data from this period may have a negative impact on the representativeness of the results of the study of tendencies in innovative entrepreneurship.

Prospects for further research will be the identification of the role of innovative entrepreneurship in the functioning of an inclusive economy.

\section{Conclusions}

The article identifies and substantiates the trends in the functioning of innovative entrepreneurship. Some of them, in particular, the growing role of the entrepreneurial sector in the production of innovations and reducing the time from the birth of an innovative idea to its realization, implementation, are positive.

At the same time, the author is concerned about the intensification of the tendency of financial and technological polarization of the world. Its essence is revealed in the strengthening of differences between countries with different degrees of economic, innovative, technological and other types of development. In particular, the World Bank's funding for projects implemented by innovative entrepreneurs from the Upper-Middle Income countries is 1.0 billion dollars higher than from the Lower-Middle Group and 0.35 billion dollars more than from the group of Low income. Also, the author draws attention to the fact that in the top 50 ranking of the Network Readiness Index in 2020, the number of countries in the High-income group was 46, and their representation, compared to 2016, increased by 2 countries.

Simultaneously with these processes, the market of frontier technologies will grow, which will significantly increase the role of innovative entrepreneurship in the world economy. The author notes that due to the change in the structure of the frontier technologies market, the largest share will be occupied by: IoT with the indicator of $46.8 \%$, and robotics - with $15.6 \%$.

\section{References}

[1] Boutillier, S. (2018). The Resources Potential of the Innovative Entrepreneur. Collective Innovation Processes, 63-85. doi: http://doi.org/10.1002/9781119557883.ch4 
[2] Crudu, R. (2019). The Role of Innovative Entrepreneurship in the Economic Development of EU Member Countries. Journal of Entrepreneurship, Management and Innovation, 15 (1), 35-60. doi: http://doi.org/10.7341/20191512

[3] Boutillier, S. (2021). Entrepreneur - The Innovative Entrepreneur as an Actor of Economic Change. Innovation Economics, Engineering and Management Handbook 1, 143-149. doi: http://doi.org/10.1002/9781119832492.ch16

[4] Juliana, N. O., Hui, H. J., Clement, M., Solomon, E. N., Elvis, O. K. (2021). The Impact of Creativity and Innovation on Entrepreneurship Development: Evidence from Nigeria. Open Journal of Business and Management, 9 (4), 1743-1770. doi: http:// doi.org/10.4236/ojbm.2021.94095

[5] Kurmaiev, P. Y., Bayramov, E. A. (2017). Current trends of financing of innovative activity entities in Ukraine. Scientific Bulletin of Polissia, 1 (2 (10)), 55-62. doi: http://doi.org/10.25140/2410-9576-2017-1-2(10)-55-62

[6] Technology and Innovation Report 2021 (2021). UNCTAD. New York: United Nations Publications

[7] Harnessing rapid technological change for inclusive and sustainable development (2020). Report of the Secretary-General. E/CN.16/2020/2. United Nations.

[8] Digital Economy Report 2019: Value Creation and Capture - Implications for Developing Countries (2019). UNCTAD. Geneva: United Nations publication.

[9] NRI (2021). Network Readiness Index. Available at: https://networkreadinessindex.org/ Last accessed: 17.09.2021

[10] Baller, S., Dutta, S., Lanvin, B. (2016). Global information technology report 2016. Geneva: Ouranos.

[11] Dutta, S., Lanvin, B. (2019). The Network Readiness Index 2019. Washington: Portulans Institute.

[12] Research and development expenditure (\% of GDP) (2021). World Bank. Available at: https://data.worldbank.org/indicator/ GB.XPD.RSDV.GD.ZS?end=2018\&locations=XO-XD\&start=2010 Last accessed: 17.09 .2021

[13] Independent Evaluation Group (2014). World Bank Group Support for Innovation and Entrepreneurship - An Independent Evaluation. Washington: World Bank.

[14] ICT price baskets data (2020). International Telecommunication Union. Available at: www.itu.int/en/ITU-D/Statistics/Pages/ ICTprices/default.aspx Last accessed: 17.09.2021

[15] Global Warming of $1.5^{\circ} \mathrm{C}(2019)$. Intergovernmental Panel on Climate Change. Geneva.

[16] Global Energy Review 2021 (2021). Paris: IEA.

[17] Kurmaiev, P. Y., Pyzhianova, N. V. (2017). Organizational and economic mechanism of state regulation of higher education system in ukraine. Scientific Bulletin of Polissia, 1 (1 (9)), 107-112. doi: http://doi.org/10.25140/2410-9576-2017-1-1(9)-107-112 